\title{
The Role of Premiums and Discounts in Business Valuation: Evidence from the Italian Context
}

\author{
Olga Ferraro ${ }^{1} \&$ Franco Ernesto Rubino ${ }^{1}$ \\ ${ }^{1}$ Department of Business Administration, University of Calabria, Arcavacata di Rende (CS), Calabria, Italy \\ Correspondence: Olga Ferraro, Department of Business Administration, University of Calabria, Arcavacata di \\ Rende (CS), Calabria, Italy. Tel: 0984-492-245. E-mail: olga.ferraro@unical.it
}

Received: December 9, 2016

Accepted: January 20, 2017

Online Published: January 26, 2017

doi:10.5539/ijbm.v12n2p83

URL: http://dx.doi.org/10.5539/ijbm.v12n2p83

\begin{abstract}
The valuation of a (non-totalitarian) shareholding in capital stock is characterized by some critical conditions, which are mainly related to the fact that the transfer or acquisition of the same can determine the transfer of control from one subject to another. It follows that the value of the investment can not simply be equal to the proportional value of the share capital, but should include premiums or discounts. Discounts and premiums do not just affect the value of a company; they play a crucial role in influencing a host of other factors and conditions that can make or break a deal. When it comes to business valuations, it is the business appraiser's responsibility to be intimately knowledgeable with every aspect of discounts and premiums: the different types, the situations when they may or may not apply, and how to quantify them. The paper has a twofold approach: on the one hand, it analyzes the main reference literature on the definition and characteristics of premiums and discounts and the recognition and quantification of the same; on the other, subsequently, it examines the behavior adopted by the Italian professional practice in recognition and appreciation of prizes and discounts.
\end{abstract}

Keywords: business valuation, discounts, premiums, non-totalitarian shareholding

\section{Introduction}

The theme of the evaluation of business has always been characterized by an interest in both the "professional" type, aimed at business owners, managers, financial operators and professional practitioners, and the "theoretical" type concerning the scholars of the best companies disciplines. The latter, in particular, have initiated an extensive scientific production initially focused on general aspects of the evaluation process, such as the development of traditional valuation methods (Onida, 1951; Ferrero, 1966, Coda, 1963; Viganò, 1967) and innovative (Romano \& Taliento, 2002), and then move towards special cases, such as the valuation of companies in crisis (Liberatore et al., 2014), the evaluation of business units (Mu-frock, 2001) or holdings (Oricchio, 1993; Onesti, 2002; Zingales, 1995).

Our work is part of the latter, with the aim to address the various issues related to the estimation of capital holdings, expressed as shares or quotas. When, in fact, the estimated object is not an entire company, but a participation in the capital, the evaluator is faced with the problem of deciding whether the value of a single share (or ideal portion) is equal to a constant average value (ratio of the value of net assets to the total number of ideal shares or quotas) or if, instead, it should vary in the ratio of: (a) the control premiums, when the unit value attributed to the shares is greater than the average value $(50 \%+1)$; (b) the minority discounts, when the unit value attributed to the shares is less than the average value.

Once limited the circumstances in which it is appropriate to make use of premium or discount, the appraiser must quantify these amounts.

If the estimate of the economic value of capital can rely upon appreciated and sedimented performance criteria proposed by doctrine and professional practices, the same cannot be said for the quantification of premiums and discounts.

Pure premiums and discounts, in fact, are not directly observable in the market and there is a lack of satisfactory theoretical models able to allow an analytical estimate that requires assumptions often unproven and therefore, extremely arbitrary by nature.

Once analyzed, therefore, the main reference literature on the definition and characteristics of premiums and 
discounts and the recognition and quantification of the same, this paper aims to examine the behavior adopted by Italian professional practice at the valuation of non-entire investments.

The study is based on an initial sample of 58 appraisals made on several occasions (bankruptcies, arrangements with creditors, transfers, disposals) dealing exclusively with the evaluation of corporate shares.

The main objective is to "observe" the modus operandi of Italian professional practice in the recognition and respect of premiums and discounts in the valuation of non-entire investments.

The study, which is part of the debate about the opportunity to make use of rewards and discounts at estimates of non-entire investments (Oricchio, 1993; Onesti, 2002; Bigelli \& Sapienza, 2003; Guatri \& Bini, 2005; Massari et al., 2004; Bernini, 2011; Ferraro, 2015) enriching the analyzes conducted on the quantification methods of premiums and discounts by Italian practice (Zingales, 1994; Dick \& Zingales, 2001; Hanouna et al., 2001; Nenova, 2003 ; Coronella, 2010).

In addition, the results arising from this "observation" are intended to help improve knowledge on the quality of appraisals made in a country like Italy, where increasingly there is a need to adopt a body of evaluation principles able to guarantee not only the estimation of provable, rational and reliable absolute values, but also a uniformity of "behavior" in the performance especially on "special" occasions such as the estimation of a non-entire participation can be.

The rest of the paper is organized as follows: Section 2 deals with the analysis of the literature on the definition, characteristics and types of premiums and discounts, as well as on domestic and foreign models and empirical evidence. The section concludes with the definition of research hypothese. Section 3 describes the research methodology and sample and data collection; Section 4 contains the main search results. The study concludes with a discussion of the main results and future research prospects.

\section{Literature Review}

In this section we analyze the main literature on the economic value of participation in the capital. After a brief review of studies aimed at further defining the characteristics and the different types of premiums and discounts on the occasion of the estimate of capital holdings, were analyzed the main models developed by the doctrine and the empirical applications for quantification of these quantities.

\subsection{Literature Review on Definition, Characteristics and Types of Premiums and Discounts}

A rough definition of control premium, also called majority premium, is the cash surplus which the shareholder is willing to pay to get control of the company. The control premium is "the extra price that is paid for the right to appoint the majority of board members" (Zingales, 2008).

The International Glossary of Business Valuation Terms defines the control premium as "the sum - expressed in currency or percent - representing the difference between the value of a controlling stake and the value of a non-controlling participation in a society".

Zanda et al. (2013) state that "control awards are a recognized plus to the value of an investment compared to the corresponding portion of the total economic capital, for the simple fact of allowing the control of a company."

In "Mergerstat Control Premium Study" the control premium is defined as "the additional consideration that an investor would pay over a marketable minority equity value in order to own a controlling interest in the common stock of a company".

In other words, the control premium represents that magnitude to be added to the base value of the company's capital, considered pro-rata basis, in order to introduce in the value of the shares the benefits and advantages that affect the person who has control of a given companies, although not possessing the entire share capital (Massari, 1989).

Regarding the recognition of that surplus value to a control package, a first approach considers that the majority of the premium comes from the possibility, on the part of those who own control, to purchase, at a later time, shares held by minority shareholders at a lower price than the commercial value of the same (theory of the shortest residual cost of capital) (Guatri \& Bini, 2005). Regarding this, Guatri (1990) notes that it is not always easy to predict the behavior of the minority shareholders. These, in fact, may not be willing to sell their shares, or to sell them at a higher price than their economic value. Moreover, in the case of listed companies it appears unlikely that the buyer of a majority stake intends to bring his stake beyond certain levels (this being due to the reduced investment theory that will be discussed later).

For others, the majority of the premium has its foundation in the possibility, on the part of the owner of the 
controlling interest, to exercise influence over the management of the bank, therefore over the typical investment risk. That argument, however, cannot be accepted as a general basis since it would materialize only in the event that the companies were operating in contexts characterized by the absence of legislation for the protection of minority shareholders.

Finally, according to another theory, the majority of the premium comes from the fact that those who buy a control package have the ability to exercise a "dominant influence" on the company through an investment below that needed to acquire the entire share capital (reduced investment theory). According to 2359 Civil Code, the control of a company can be classified in three main categories: i) the holding of an absolute majority of the votes at the meeting (of law enforcement); ii) possession of a share package of a size such as to guarantee the exercise a dominant influence on the resolutions approved there; iii) the existence of contractual obligations such as to enable a dominant influence on the business.

From the above, it follows that control can be exercised both through the ownership of the absolute majority of shares and through minority shareholdings that are able nevertheless to attribute the relative majority of the votes in the ordinary shareholders' meeting. In the present study, the control word is used both to refer to questions of the absolute majority packages, as well as those of de facto control carriers.

In these terms, therefore, the majority of the premium should be recognized on packages lower than $100 \%$, in an increasing percentage to the diminuation of the representative quota of the package, reaching the upper limit in correspondence to a representative package of the minimum percentage of sufficient properties to ensure control (usually 50\%+1) (Onida, 2005, p. 663).

Instead, as regards the minority discount this is understood as the lower value recognized to a share that does not give the benefits of the participatory control; it can also be affected by the lower tradability of a minority stake compared to a controlling stake, thus becoming assimilated to a discount for lack of liquidity (Bertoni \& De Rosa, 2014).

In practice it often happens that a minority discount is considered the opposite of the control premium, although that does not mean equivalence quantitatively (Guatri, 1998), while according to others (Onesti, 2002; Coronella, 2010) the minority discount, when not confused with the lack of marketability leading to c.d. liquidity discount, either it does not exist, or it exists in extreme cases.

The definition of premiums and discounts is therefore not as clear-cut as one might think and the issue should be dealt with great caution taking into account the possible types that can be identified with respect to different categories of investments subject to valuation (Ferraro, 2015) and situations (first owner, corporate governance model structure) in which premiums and discounts should apply.

\subsection{Literature Reviews on Quantification of Premiums and Discounts}

The analytical estimate of premiums and discounts implies the definition of hard-driver identification and quantification that require assumptions often unproven and therefore, by nature, extremely arbitrary. Over time, however, the company's economic doctrine has developed some methods that allow you to estimate the value (Oricchio, 1993; Barclay \& Holderness, 1989; Zingales, 1995) and which then found empirical application over the years in various countries, namely taking into account the different types of packets exchanged and the perspective adopted (Dick \& Zingales, 2004; Massari et al., 2004; Hanouna et al., 2001; Nicodamo \& Sembenelli, 2000; Linciano, 2002; Zingales, 1994; Nenova, 2003; Bigelli \& Sapienza, 2003).

Although, in fact, it being the more neutral theoretical approach because it is not based on data of previous transactions, the complexity of the elements that make up a control premium (and a discount), is too simplistic and one runs the risk of committing errors of assessment. From here the recourse to an empirical approach in professional practice generally based on available information of previous transactions, of course, selecting the transations of those companies with features that are closest to the transaction that requires an evaluation.

Despite the extensive use of the empirical approach, also it brings some limitations. In the first place, one must consider that information is only available regarding listed companies, while in practice very often this information is used for the calculation of non-listed companies control premiums. Furthermore, the measured data have a strong dispersion, which influences the average calculated. Using the median solves the problem; in any case, however, its significance is not always great, because the sample is often very low, especially because in narrow time spans there are quite few control vertex exchange transactions.

Table 1 presents the the main models developed by the doctrine and the empirical applications for quantification of Premiums and Discounts. 
Through analysis of the studies reported in Table 1 it is possible to identify different ranges of value attributable to premiums and discounts depending on the model or empirical research that is followed.

Table 1. The model and empirical studies for estimating Premiums and Discounts

THE MODELS FOR ESTIMATING PREMIUMS
ASSUMPTION
$\begin{aligned} & \text { The box model diagram (or chart "in the box") is based on the assumption of the } \\ & \text { presence of two simplistic shareholders (A and B) who divide the totality of the } \\ & \text { investments related to a company. } \\ & \text { The basic assumption of the proposed model is that the price observed in the market } \\ & \text { in which minority packages are exchanged is capable of incorporating the change in } \\ & \text { value suffered by the actions widespread once news breaks of the transfer of control } \\ & \text { of the company. } \\ & \text { Barclay \& Holderness (1989) } \\ & \text { The model is based on the distinction between actions with voting and non-voting } \\ & \text { rights inferring the control value from the difference in prices of the two categories } \\ & \text { of shares. The idea is that the shares traded on the stock market with the right to } \\ & \text { vote, although not belonging to the control package, incorporating part of the private } \\ & \text { benefits and, therefore, are deserving of a plus value compared to those without the } \\ & \text { right to vote. }\end{aligned}$

\section{EMPIRICAL EVIDENCE}

STUDY

Dick and Zingales (2004)

\section{PERIOD}

$1990-2000$

Massari, Monge \& Zanetti (2004)

Hanouna, Sarin \& Shapiro (2001)

Nicodamo \& Sembenelli (2000)

Linciano (2002)

Zingales (1994)

Nenova (2003)

Bigelli \& Sapienza (2003)

STUDY

Mercer Capital Inc.

Moroney

Maher

Silber

Gelman

Trout

Willammette

Management planning, Inc

SEC Institutional Investor

FMV Options, Inc

Columbia Financial Advisors (I)

Johnson

Finnerty

Harris

Hertzel \& Smith

Columbia Financial Advisors (II)

Bajaj, Denis, Ferris and Sarin

W. Baird \& Co.

Willamette Associates
1993-2003

1986-2000

1987-1992

1989-2000

1987-1990

1997

2000-2002

PERIOD

1988-1995

1969-1973

1969-1973

1981-1988

1968-1970

1986-1972

1891-1984

1980-1995

1966-1969

1980-1997

1/1996-04/1997

1991-1995

1991-1997

2007-2008

1980-1987

5/1997-12/1998

1990-1995

1980-2000

1891-1984

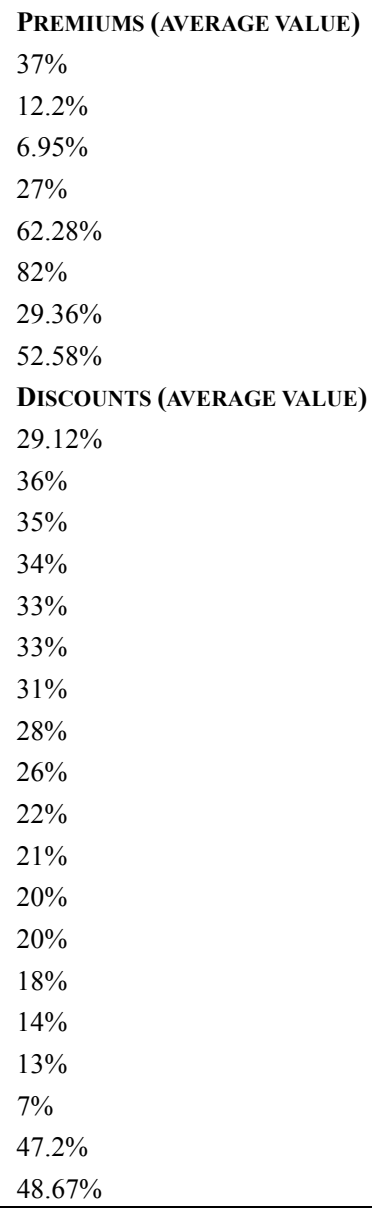

From the analysis of different studies reported in the Table 1, as is apparent that whereas for the doctrine majority premiums can be attributed, a value which abuts in a range between $15 \%$ and $30 \%$, according to the characteristics of the company to be evaluated, empirical research has identified a reasonable range for the listed 
companies of between $12 \%$ and $18 \%$ in Italy, so that would overlap with the minimum indicated by the doctrine.

The present research work is driven from the above-described framework. In particular, through the analysis of a sample of expert appraisals relating to the valuation of non-entire investments, it was intended to verify, first, the recognition by the Italian professional practice of premiums and discounts and then subsequently to analyze quantification of the same modality.

The research hypothesis are, therefore, the following:

H1: Verify whether the experts, in the implementation of the evaluation process for the estimation of a non-entire investment, recognize a plus (or minus) value as majority premium (or minority discount);

H2: Verify, if recognized, the methods of quantification of premiums or minority discounts.

\section{Sample and Methodology}

In order to investigate the objectives defined above the modus operandi of professional practice was observed through the analysis of a sample of appraisals made by Italian experts on several occasions (bankruptcies, extraordinary operations) and covering covered only the evaluation of equity investments. Through observation of the behavior adopted by the valuation practice, this study helps to improve knowledge on the quality of valuation reports drawn up in Italy where only recently, however, the principles of evaluation were introduced on a voluntary basis. The collection of the reports was carried out directly from the web, on several sites dedicated to the judicial auctions and on the Italian Stock Exchange web site, or by the courts involving the on line deposit of the same. In order to broaden the sample being analyzed, also an alternative search mode was adopted contacting professional firms that operate in the field of business valuation.

The initial sample of 58 surveys was then reduced by 10 reports relating to the estimate of totalitarian investments for which recognize premiums or discounts are not recognized. The methodology used for the collection of quantitative information necessary to test the research hypotheses included the construction of a check list developed on three levels of information. In line with Ferraro \& Liberatore (2016), the first level includes the essential requirements that a valuation report should possess in order to be described as adequate, regardless of the subject to be evaluated, and that refers to the minimum content required in the accounting principles IVS 101 - Scope of Work and IVS 103 - Reporting issued by the International Valuation Standards Council (IVSC), as well as the Italian Valuation Principles (PIV) issued by the OIV.

The second level of the check list regards those aspects that allow the expert to: i) qualify the type of ownership interest being valued and whether the packet transfers some (or all) of the powers of control, ii) analyze the equity interests held by other shareholders and assess the potential effect on the value of the ownership interest being valued; iii) understand the characteristics of the stock and the related rights; iv) include all the elements that can affect the value of the participatory interest; v) verify the information which can be accessed (see. PIV, III.3.2.).

Finally, the third level of the check list is focused on the collection of information concerning: a) the rules for estimating the value base to the company's capital; b) the reasons for the award of majority premiums or minority discounts, if any; c) the procedures for quantifying the majority premiums or minority discounts used by the appraiser to estimate the final economic value attributed to non-entire investment.

The degree of presence of this information in the estimation allows us to provide an overall opinion on the quality with which they have been drawn up based on the following parameters (Ferraro and Liberatore, 2016):

- $\quad$ "adequate" when the valuation reports have at least the minimum content requirements in the first level of the check list;

- $\quad$ "good", when in addition to the minimum content the valuation reports present detailed information on the second level of the check list;

- $\quad$ "very good" when the valuation report, accompanied by a minimum content and detailed information, is enhanced by a clear explanation of the mode of analytical quantification of premiums and discounts.

To test the degree of quality of the valuation reports in the sample, for each of them the presence (or not) of the information provided in the three levels of check list were found. While, to test the research hypotheses, only the information relevant to the second and third level of the check list was considered. In fact, while the information on the first level is generic and common to all valuation reports, so regardless of the purpose for which it is made (eg. a state of crisis faced by the company) those of the second and third level refer specifically to the estimation of their shareholdings and, therefore, are closely related to our goals.

The next section presents the empirical results of the analysis conducted on the basis of the methodological 
process thus far outlined.

\section{Results}

\subsection{Quality in Valuation Reports}

From an examination of the object of study reports a positive opinion can be expressed about the degree of transparency and completeness of the same in terms of basic information. With reference to the first level of the check list made we have verified, in fact, that in the totality of the sample analyzed the evaluators set, albeit in different ways, their report with a broad and clear information on the aspects that constitute the minimum content required by IVS 101 and 103 and PIV. In so far, however, as the valuation report should present the most detailed aspects regarding the more specific object of the ownership interests, the lack of information starts to appear.

In particular, with regard to the second level of the check list, against information, albeit minimal, about the identification of the type of ownership interest under valuation, rights and/or control powers transferred with the ownership and the elements that can affect the ownership interest value, the study shows strong lack of information about the shares held by other shareholders and the potential effect on the value of the ownership interest being valued.

With reference to the third level of the check list, from the research it emerges how in all the reports analyzed the the rules for estimating the value of the company's capital base are indicated in detail, whereas where there are any premiums or discounts, the motivations underlying their recognition appear limited and superficial. Finally, as we shall see in the next paragraph, in no case analyzed was an attempt made to quantify analytically the majority premiums or minority discounts awarded and they limit themselves to definitions at flat rates.

In conclusion, wanting to make a judgment on the quality of appraisals made by Italian professionals it can be said that they have a minimum of information content, but are in most cases lacking in specific information on the recognition mode and quantification of premiums and discounts.

\subsection{The Modus Operandi of the Italian Professional Practice}

From the analysis of sample surveys dealing exclusively with the estimate of non-entire investments it emerged how in $79 \%$ of cases the value of the share is determined simply by applying the ownership percentage of share capital to the value of the structures estimated by the assessment methods that the expert considered it more appropriate to adopt.

In particular, in all valuation reports observed the valuation of the investment was made through an evaluation process in three stages:

- Estimate of the economic value of the company as a whole, through the traditional application of the evaluation methods without the subjects suffering any adjustment in the evaluation parameters;

- Estimate of the value base, determined by applying to the entire capital value of the company the representative percentage of the share investment ;

- Estimates of premiums (or discounts) that, by adjusting (increasing or decreasing) the proportional value, lead to the estimate of the shareholding.

In only 10 cases, the appraiser provided for an adjustment of the quota, the translation of the premium or discount. Of these, in 6 cases a majority premium and in 4 a minority discount was recognized: a special case is to be found in the "estimate of shares equal to $98 \%$ of the capital of the company Beltservice Srl owned by Industria Gomma Srl subject to bankruptcy proceedings", where despite a stake in the share capital of $98 \%$ being transferred, a minority discount is estimated owing to failure to possess the entire stake.

In summary, based on the results obtained from the analysis of the 48 appraisals it shows how the Italian professional practice called upon to estimate the non-entire company shares rarely proceed to the analytical estimate of premiums and discounts.

Such an attitude could be attributable to difficulties in the implementation of a process of quantification of premiums and discounts for which the definition of difficult to identify and quantify drivers would be needed which require often unproven and therefore, by nature, extremely arbitrary assumptions.

The study shows, in fact, how the professional practitioner falls back more easily on the application at flat rates to be applied to the value of the economic capital fraction, the object of the buying and selling. These percentages, an expression of the empirical evidence often conducted on (crude) price differences, range from a single percentage to the identification of variable percentages according to the percentage of share capital subject 
to sale by presenting in either case a number of limitations. The fixed percentage has the obvious limitation of determining an increasing majority premium with an increase in the purchase share, in contrast to the assumptions that underlie the recognition of a majority premium. Variable percentages, on the other hand, have their limit in the extreme arbitrariness of their determination.

Finally, it should be noted that the practitioner very often merely indicates the percentage attributed to the premium or discount without any explanation about the procedures for defining the above requirement.

\section{Concluding Remarks and Suggestions for Future Research}

In this study it was intended to "observe" the modus operandi of the Italian professional practice in the recognition and respect of premiums and discounts in the valuation of non-entire investments with a twofold objective:

- To contribute to the debate in national and foreign literature, about the recognition and quantification of premiums and discounts on the occasion of estimates of non-entire investments;

- Evidence of the quality of the valuation reports produced by Italian professionals involved in the estimation of non-entire investments.

The analysis was conducted on a sample of 58 expert appraisals relating to the estimation of equity investments.

Regarding the first objective, the analysis of the main literature (Oricchio, 1993; Zingales, 1994; Dick \& Zingales, 2001; Hanouna et al., 2001; Onesti, 2002; Nenova, 2003; Bigelli \& Sapienza, 2003; Massari et al., 2004; Guatri \& Bini, 2005; Coronella, 2010; Bernini, 2011) has shown how the valuation of non-entire investments, with the subsequent award of the control premium (or minority discounts) can be complicated and multifaceted.

The difficulties of the subject emerge already in a first phase when trying to define a value base on which to apply an eventual premium (or discount) then further complicated when the expert, recognizing the need to rectify the value basis, wants to carry out a proper quantification of these quantities.

As already highlighted, while one can rely on the estimation criteria for the estimation of the value basis, for the calculation of the control premium (or discount) it is necessary to rely on an analysis able to retrieve those economic determinants that take account of the different degrees of control of the enterprise by holders of venture capital.

In other words, in the estimation of the control premium account must be taken of the probability of obtaining private benefits associated with it, corresponding to investments that are associated with administrative rights in different fields.

The rights exercised through the ownership of a given investment are also determined by the regulations in force in the country of the company and by the articles of incorporation of the same. The administrative rights of an investment, in turn, impact on the extent of the powers of control which, as noted, are directly related to deriving private benefits. From the above, therefore, the link is clear between the size of the investment, considered together with the rights which it bears, the distribution of capital to shareholders and the amount of premiums and discounts related to the control.

The observation of the behavior adopted by professional practitioners in the estimation of premiums and discounts highlighted the ease of use of the same application at flat rates to be applied to the value of the bought and sold economic capital fraction. These percentages, an expression of empirical evidence often conducted on (crude) price differences, range from a single percent to the identification of variable percentages according to the percentage of share capital subject to sale by presenting a number of limitations in either case. The fixed percentage has the obvious limitation of determining a majority premium increasing with increasing purchase share, in contrast to the assumptions that underlie the recognition of a majority premium. The variable percentages have, on the other hand, their limit in the extreme arbitrariness of their determination.

Finally, it should be noted that very often the professional practitioner merely indicates the percentage attributed to the premium or discount without any explanation as to the mode of defining the above requirement.

As regards the quality of the analyzed reports, in line with previous studies (Ferraro and Liberator, 2016) it can be said that they present a minimum of information content, but are deficient in the majority of cases in terms of specific information on the object of the evaluation and, with reference to the object of our study, the recognition mode and quantification of premiums and discounts.

The valuation reports are also very heterogeneous among them in terms of content and exposure modes of the 
information as well as in the implementation of the estimate process and in those measures, which are often conflicting also in "similar occasions".

This leads to the need that also in Italy as occurs with the budget, the experts have to adopt a body of recognized and appreciated valuation principles able to drive to the estimate of provable, rational and reliable absolute values, and so ensure a uniform attitude.

The main limitation of the study lies in the reduced sample size and extent of the period investigated which suggests caution in interpreting the behavior of Italian professional practice.

Among the positive elements of the study it should be emphasized that it is the first study to investigate the modus operandi of Italian professional practice in calculating the majority or minority discounts awards as part of the estimate of a non-entire investment.

Any such thematic developments could be deepened by expanding the number of surveys examined, referring for example to collecting "papers" filed with the courts.

Further insights into the analysis may have as object an extension of the investigation to other countries with the aim of making a comparison with international professional practice in occasion of "similar" situations.

\section{Acknowledgments}

We are grateful to the Editors and the anonymous reviewer, whose many invaluable comments improved the substance of the paper. Although the paper is the result of an equal joint effort by the two authors, their primary individual contributions are reflected in the following sections of the paper: Olga Ferraro: 2.1, 2.2, 3, 4.2, 5; Franco Ernesto Rubino: 1, 4, 4.1.

\section{References}

Barclay, M. J., \& Holderness, G. (1989). Private Benefits from Control of Public Corporations. Journal of Financial Economics, 25, 371-395. http://dx.doi.org/10.1016/0304-405X(89)90088-3

Bernini, F. (2011). I pacchetti azionari. Analisi del fenomeno e aspetti valutativi. Milano: Giuffrè.

Bigelli, M., \& Sapienza, E. (2003). Le azioni di risparmio e gli errori di misurazione del premio per il diritto di voto. Banca, Impresa e Società, 1, 67-96. http://www.rivisteweb.it/doi/10.1435/8637

Coda, V. (1963). Introduzione alle valutazioni dei capitali economici di impresa. Milano: Giuffrè.

Coronella, S. (2010). Premi di maggioranza e sconti di minoranza nella valutazione delle partecipazioni: Un approccio empirico. Rivista dei Dottori Commercialisti, 1, 99-113.

Dick, A., \& Zingales, L. (2001). Private Benefits of Control: An International Comparison. The Journal of Finance, $\operatorname{LIX}(2), 537-598$.

Ferraro, O. (2015). La stima del valore economico delle partecipazioni. Il ruolo dei premi e degli sconti. FrancoAngeli: Milano.

Ferraro, O., \& Liberatore, G. (2016). Analyzing Business Valuation Quality of Disclosures for Distressed Italian Companies. From a Legally Respectful Approach to the Sustainability of Turnaround Assessment. International Journal of Business Research, 16(2), 7-26. http://dx.doi.org/10.18374/IJBR-16-2.1

Ferrero, G. (1966). La valutazione economica del capitale d'impresa. Giuffrè: Milano.

Gelman, M. (1972). An Economist-Financial Analyst's Approach to Valuing Stock of a Closely Held Company. Journal of Taxation, June, 353-354.

Gianfrate, G. (2006). La misurazione dei "benefici privati del controllo": Lo stato dell'arte e prospettive. $L a$ Valutazione dell'azienda, 42, 29-45.

Guatri, L. (1990). La valutazione delle aziende. Teoria e pratica a confronto. Milano: Egea.

Guatri, L. (1998). Un approccio alla misura dei premi di controllo. La valutazione delle aziende, 8.

Guatri, L., \& Bini, M. (2005). Nuovo trattato sulla valutazione delle aziende. Milano: Università Bocconi Editore.

Hanouna, P., Sarin, A., \& Shapiro, A. (2001). Value of Corporate Control: Some International Evidence, Marshall School of Business, Working Paper Series, 1-4. http://dx.doi.org/10.2139/ssrn.286787.

Hinteruber, A. (1996). La valutazione delle imprese in Germania. Risultati di una ricerca empirica. La valutazione delle aziende, 2.

Hitchner, J. R. (2006). Financial Valuation. Application and Models, second edition, Wiley \& Sons, Hoboken. 
Houlihan Lokey Howard Zukin (1995). Control Premium Study, 1st quarter 1995, Los Angeles.

Linciano, N. (2002). Azioni di risparmio e valore del controllo: Gli effetti della regolamentazione. Quaderni di Finanza. Studi e ricerche Consob, 53.

Maher, M. J. (1976). Discounts for Lack of Marketability for Closely Held Business Interests. Taxes, September, $562-571$.

Massari, M. (1989). Valore dei pacchetti di controllo e «premio di maggioranza». Finanza, Marketing $e$ Produzione, 1, 139-153.

Massari, M., Monge, V., \& Zanetti, L. (2004). Control premium in the presence of rules imposing mandatory tender offers: can it be measure?, working paper, Università Bocconi, IASFC.

Mercer, C. Z. (1997). Quantifying Merketbility Discount: Developing and Supporting Marketability Discount in the Appraisal of Closely Held Business Interest, Memphis: Peabody Publishing.

Moroney, R. E. (1973). Most Courts Overvalue Closely Held Stocks. Taxes, March, 144-154.

Musaio, A. (2001). Il trasferimento del ramo d'azienda, Milano: FrancoAngeli.

Nenova, T. (2003). The Value of Corporate Voting Rights and Control: A Cross-Country Analysis. Journal of Financial Economics, 68, 325-351. http://dx.doi.org/10.1016/S0304-405X(03)00069-2

Nicodano, G., \& Sembenelli, A. (2000). Private benefits, Block Transaction Premia and Ownership Structure. Zimmerman Foundation for the Study of Banking and Finance, Discussion paper.

Onesti, T. (2002). Sconti di Minoranza e sconti di liquidità. Padova: Cedam.

Onida, P. (1951). Le dimensioni del capitale d'impresa. Milano: Giuffrè.

Onida, P. (2005). Economia d'azienda. Torino: Utet.

Oricchio, G. (1993). Osservazioni metodologiche in ordine alla determinazione dei premi di maggioranza e degli sconti di minoranza nella valutazione di pacchetti azionari. Rivista Italiana di Ragioneria e di Economia Aziendale, 11/12, 592-600.

Romano, M., \& Taliento, M. (2002). Economic Value Added (E.V.A.) e Unlevered Discounted Cash Flow (U.D.C.F.) nella valutazione delle aziende. Rivista Italiana di Ragioneria e di Economia aziendale, 7(8), 354-370.

Silber, W. L. (1991). Discounts on Restricted Stock: the Impact of Illiquidity on Stock Prices. Financial Analysts Journal, August, 60-64. http://dx.doi.org/10.2469/faj.v47.n4.60

Trout, R. R. (1977). Estimation of the Discount Associated with the Transfer of Restricted Securities. Taxes, June, 381-385.

Viganò, E. (1967). La natura del valore economico del capitale d'impresa e le sue applicazioni. Napoli: Giannini.

Zanda, G., Lacchini, M., \& Onesti, T. (2013). La valutazione delle aziende. Torino: Giappichelli.

Zingales, L. (1994). The value of the voting rights: A study of the Milan stock exchange experience. Review of Financial Studies, 7, 125-148. http://dx.doi.org/10.1093/rfs/7.1.125

Zingales, L. (1995). What Determines the Value of Corporate Votes? The Quarterly Journal of Economics, 110, 1047-1073. http://dx.doi.org/10.2307/2946648

Zingales, L. (2008). Premio di controllo e conflitti di interesse. Il Sole 24 ore, 15 luglio.

\section{Copyrights}

Copyright for this article is retained by the author(s), with first publication rights granted to the journal.

This is an open-access article distributed under the terms and conditions of the Creative Commons Attribution license (http://creativecommons.org/licenses/by/4.0/). 